\title{
Management of Soil Acidity and Its Relations With Soybean Productivity in Brazilian Savanna
}

\author{
Camila Morais Fonseca ${ }^{1}$, Veridiana Cardozo Gonçalves Cantão ${ }^{1}$, Carlos Cesar Evangelista de Menezes ${ }^{1}$, \\ Simone Cristiane Brand ${ }^{2}$, Gabriel Elias Soares de Araújo ${ }^{1}$, Raquel de Sousa Neta ${ }^{1}$, Rose Luiza Moraes Tavares ${ }^{1}$, \\ Paulo Fernandes Boldrin ${ }^{1}$, June Faria Scherrer Menezes ${ }^{1} \&$ William Peres ${ }^{3}$ \\ ${ }^{1}$ Agronomy College, Rio Verde University, Rio Verde, Brazil \\ ${ }^{2}$ PlantCare Experimental Station, Ribeirão Preto, Brazil \\ ${ }^{3}$ Center for Chemical, Pharmaceutical and Food Sciences, Federal University of Pelotas, Pelotas, Brazil \\ Correspondence: Veridiana Cardozo Gonçalves Cantão, Agronomy College, Rio Verde University, Fazenda \\ Fontes do Saber, P.O. Box 104, Rio Verde-GO, Zip Code 75901-970, Brazil. Tel: 55-(64)-3611-2291. E-mail: \\ veridiana@unirv.edu.br
}

Received: October 20, 2021

Accepted: November 28, $2021 \quad$ Online Published: December 15, 2021

doi:10.5539/jas.v14n1p50

URL: https://doi.org/10.5539/jas.v14n1p50

The research is financed by University of Rio Verde-UniRV and the Fundação de Amparo à Pesquisa do Estado de Goiás-FAPEG.

\begin{abstract}
The soils of Brazilian Savanna, naturally, present acidity problems, making correction practices fundamental to ensure production. Even with so many years since the introduction of agriculture, some soil correction practices are still misused. Thus, the objective was to evaluate soybean yield and chemical changes in a Red Oxisol in the Brazilian Savanna with the use of limestone, associated or not with gypsum, applied superficially and incorporated by harrow and moldboard plow. The experiment was conducted under field conditions, in Rio Verde-GO, cultivating soybeans in the 2015/2016 and 2016/1017 harvests. The experimental design was in randomized blocks, with four replications, with treatments arranged in a $3 \times 3$ factorial scheme. The first factor refers to the application of superficial limestone and incorporated by harrow and moldboard plow. The second factor was the presence or absence of limestone and/or gypsum $\left(0+0 ; 0.875+0\right.$ and $\left.0.875+1.75 \mathrm{tha}^{-1}\right)$. Plant height, number of pods per plant, productivity, $\mathrm{pH}, \mathrm{Al}, \mathrm{CTC}, \mathrm{Ca}, \mathrm{Mg}$ and $\mathrm{V}$ were evaluated, in soil depths of 0-0.2 and 0.2-0.4 m. In the 2016/2017 harvest, the characteristics of pH, CTC, V and contents of $\mathrm{Ca}, \mathrm{Mg}$ and $\mathrm{Al}$ were influenced by the methods of application of limestone and by its use, associated or not with gypsum. There was an increase in $\mathrm{pH}$ on the soil surface with the use of limestone and on the subsurface with the use of limestone and gypsum. The moldboard plow provided increases in the contents of $\mathrm{Ca}$ and $\mathrm{Mg}$ in the soil in comparison to surface application. The moldboard plow incresed in soybean yield, in the second crop, with and without association of gypsum with limestone.
\end{abstract}

Keywords: limestone, plaster, moldboard, harrow

\section{Introduction}

Soils with advanced weathering, such as those in the Southwest region of Goiás, have physicochemical characteristics that limit crop productivity. Thus, this region stands out in grain production due to the advance of agricultural practices. In this sense, soil fertility management is essential to keep the region competitive in the national production scenario.

The liming and plastering practices provide a favorable soil environment for the development of plants, as the correctives, with emphasis on limestone, and gypsum provides calcium and/or magnesium for the plants and minimizes the effects of surface and subsurface acidity of the soil (Caires, Garbuio, Churka, Barth, \& Corrêa, 2008; Souza et al., 2012). The limestone efficiency is given by the corrective dose applied (based on analysis results), if it was applied superficially or incorporated, in case of incorporation, at what depth this occurred and the corrective's relative endowment neutralizing power (PRNT). 
Thus, defining the dose of limestone and how it will be distributed in the production area will have direct implications for crop productivity. It is noteworthy that limestone, due to its low solubility in the soil, needs time for its particles to react, bringing the necessary chemical benefits to cultivated areas (Caires, Blum, Barth, Garbuio, \& Kusman, 2003).

The use of implements such as moldboard plow and harrow optimizes the reaction of limestone in the soil, favoring its efficiency. However, the continued adoption of harrowing and plowing does not provide an increase in soil organic matter (SOM) (Sá et al., 2009). It is known that the increase in SOM, especially in kaolinitic soils that are representative in the Southwest of Goiás, implies many chemicals, physical and biological benefits in the soil, favoring the sustainability of the production system (Sá et al., 2009; Moraes et al., 2019; Ferreira, Tavares, Medeiros, Silva, \& Silva Júnior, 2020).

Thinking about accumulating SOM, the superficial application of limestone was intensified and to minimize the effects of soil acidity in the subsurface, gypsum, being very soluble in the soil, started to be adopted (Caires et al., 2003). Furthermore, the application of gypsum in Brazilian Savanna soils has resulted in plant resilience in periods of drought (Marchi, Spehar, Sousa-Silva, Guilherme, \& Martins 2020). Based on the above, the objective was to evaluate soybean yield and chemical changes in a Red Oxisol in the Brazilian Savanna with the use of limestone, associated or not with gypsum, applied superficially and incorporated by harrow and moldboard plow.

\section{Method}

The experiment was conducted in the experimental area of the Institute of Science and Technology of the Agroindustrial Cooperative of Rural Producers of Southwest Goiano (ITC-COMIGO), in the municipality of Rio Verde-Goiás, in two agricultural years: 2015/2016 and 2016/2017 harvests. The soil in the experimental area is classified as Dystrophic Red Oxisol (Santos et al., 2018), with 555,87 and $356 \mathrm{~g} \mathrm{~kg}^{-1}$ of sand, silt and clay in the 0-0.2 $\mathrm{m}$ layer and $622,104,273 \mathrm{~g} \mathrm{~kg}^{-1}$ in the $0.2-0.4 \mathrm{~m}$ deep layer.

In the 10 years prior to conducting the experiment, the experimental area was conducted no tillage soil, cultivating soybean and corn in a succession system. The fertilizations performed during this period followed the technical recommendations based on the results of soil analyses. The application of treatments with limestone and gypsum was carried out in the 2015/2016 harvest, based on the results of the soil analysis (Table 1). Subsequent to the application of treatments, soybean sowing was carried out.

Table 1. Chemical characteristics of a Dystrophic Red Oxisol from Brazilian Savanna in Rio Verde/GO

\begin{tabular}{|c|c|c|c|c|c|c|c|c|c|}
\hline Depth & $\mathrm{pH}$ & $\mathrm{Ca}$ & $\mathrm{Mg}$ & $\mathrm{Al}$ & $\mathrm{H}+\mathrm{Al}$ & CTC & $\mathrm{K}$ & \multirow{2}{*}{\multicolumn{2}{|c|}{$\frac{\mathrm{P}_{\text {Mehlich-1 }}}{\mathrm{mg} \mathrm{dm}^{-3}}$}} \\
\hline $\mathrm{m}$ & $\mathrm{CaCl}_{2}$ & \multicolumn{6}{|c|}{ |-------------------------------- $\mathrm{cmol}_{\mathrm{c}} \mathrm{dm}^{-3}$------------------------------- } & & \\
\hline $0-0.2$ & 4.54 & 1.65 & 0.58 & 0.14 & 3.54 & 5.63 & 0.23 & 19.89 & \\
\hline $0.2-0.4$ & 4.51 & 0.94 & 0.20 & 0.32 & 3.33 & 4.56 & 0.10 & 22.30 & \\
\hline Depth & $\mathrm{OM}$ & $\mathrm{V}$ & B & $\mathrm{Fe}$ & $\mathrm{Mn}$ & $\mathrm{Zn}$ & $\mathrm{Co}$ & $\mathrm{Na}$ & $\mathrm{Cu}$ \\
\hline $\mathrm{m}$ & $\mathrm{g} \mathrm{dm}^{-3}$ & $\%$ & ----- & - & -------- & $\mathrm{dm}^{-3}$ & ----- & ------. & ------- \\
\hline $0-0.2$ & 19.99 & 38.44 & 0.14 & 100.80 & 28.96 & 18.11 & 0.14 & 2.42 & 0.43 \\
\hline $0.2-0.4$ & 14.07 & 25.94 & 0.14 & 125.79 & 11.98 & 7.40 & 0.10 & 1.22 & 0.39 \\
\hline
\end{tabular}

Note. CTC: cation exchange capacity; OM: organic matter; V: base saturation.

The experiment was carried out in a randomized block design in a $3 \times 3$ factorial scheme with 4 replications. The first factor was composed of three methods of limestone incorporation (surface, incorporated with a 36-inch harrow and incorporated with a moldboard plow). The second factor was the management of acidity through the application of limestone alone $\left(0.875+0 \mathrm{t} \mathrm{ha}^{-1}\right)$ or associated with gypsum $\left(0.875+1.75 \mathrm{t} \mathrm{ha}^{-1}\right)$ and a treatment without application of inputs $(0+0)$.

The base saturation method (Raij et al., 1987), aiming to increase it to $65 \%$, was used to calculate the liming requirement (LR). Based on the results of the soil analysis of the experimental area (Table 1), the LR calculated by the method was $1.75 \mathrm{t} \mathrm{ha}^{-1}$. This dose considers the incorporation of limestone at a depth of $0.2 \mathrm{~m}$ and adjustment to the PRNT of the corrective used (described below). However, the adoption of a dose of limestone of $0.875 \mathrm{t} \mathrm{ha}^{-1}$ and gypsum of $1.75 \mathrm{t} \mathrm{ha}^{-1}$ used was in accordance with the acidity management adopted by producers in Southwest Goiás. 
In countless farms in the region, due to direct seeding, the doses mentioned are used, applied on the surface. However, in situations where there are problems related to acidity and/or soil compaction, limestone is incorporated by harrows and moldboard plows, without dose correction due to the effective working depth of the implements. In these situations, the gypsum is used together with the recommended dose of limestone for application without incorporation, with the purpose of the gypsum to reduce the problems of acidity in the subsoil.

The limestone used contained 90.8\% PRNT, 94.13\% neutralizing power (PN), 96.46\% relative efficiency (RE), $32.2 \%$ calcium oxide $(\mathrm{CaO})$ and $14.7 \%$ magnesium oxide $(\mathrm{MgO})$. Agricultural gypsum had $8.3 \%$ calcium, $15.96 \%$ sulfur and $28 \%$ moisture.

The surface and incorporated application of limestone was carried out on 12/3/2015 and gypsum on 12/17/2015, with plastering performed by surface application without incorporation. It is noteworthy that the application of inputs and limestone incorporation operations took place only in 2015. For the purpose of comparing the efficiency of the method adopted in limestone incorporation, the use of the harrow and the moldboard plow was also adopted in the reference plots $\left(0+0 \mathrm{t} \mathrm{ha}^{-1}\right)$.

The first crop occurred with the sowing of soybean, cultivar Anta 82RR, on 12/15/2015, with an average rainfall during the period of $848 \mathrm{~mm}$. In the second, cultivar M7739 IPRO was sown on 11/10/2016, with average rainfall of $874 \mathrm{~mm}$ during the crop cycle.

In both crops, seed inoculation was used with $600 \mathrm{~mL} \mathrm{ha}^{-1}$ of the Biomax Premium inoculant, with a minimum of $6 \times 10^{9}$ viable cells per $\mathrm{mL}$, of the Bradyrhizobium strains SEMIA 5079 and 5080 . At this time, $50 \mathrm{~mL} \mathrm{ha} \mathrm{a}^{-1}$ of the product NHT CoMo (24.9 $\mathrm{g} \mathrm{ha}^{-1}$ Mo and $2.49 \mathrm{~g} \mathrm{ha}^{-1} \mathrm{Co}$ ) was also applied to the seed furrow in a final volume equivalent to $60 \mathrm{~L} \mathrm{ha}^{-1}$.

The fertilization for the 2015/2016 and 2016/2017 harvests was performed with the application of $250 \mathrm{~kg} \mathrm{ha}^{-1}$ of MAP Turbo (monoammonium phosphate + micronutrients) in the seed furrow. This dose represented the supply of 25 and $125 \mathrm{~kg} \mathrm{ha}^{-1}$ of $\mathrm{N}$ and $\mathrm{P}_{2} \mathrm{O}_{5}, 0.38 \mathrm{~kg} \mathrm{ha}^{-1}$ of $\mathrm{Zn}$ and $\mathrm{Mn}$ and $0.18 \mathrm{~kg} \mathrm{ha}^{-1}$ of $\mathrm{Cu}$ and $\mathrm{B}$. Potassium fertilization was carried out with $\mathrm{KCl}$ (potassium chloride) at a dose of $120 \mathrm{~kg} \mathrm{ha}^{-1}\left(70 \mathrm{~kg} \mathrm{ha}^{-1} \mathrm{~K}_{2} \mathrm{O}\right)$.

Each experimental plot had 12 sowing lines with $20 \mathrm{~m}$ in length, spaced $0.5 \mathrm{~m}$ apart, totalling $120 \mathrm{~m}^{2}$. The evaluations were carried out in the useful area of $10 \mathrm{~m}^{2}$ of each plot. The following characteristics were evaluated: plant height and number of pods per plant (10 plants of the useful area), productivity (total harvest of the useful area and adjustment of grain moisture to $13 \%)$ and in the soil $(0-0.2$ and $0.2-0.4 \mathrm{~m}) \mathrm{pH}, \mathrm{Al}, \mathrm{CTC}, \mathrm{Ca}$, $\mathrm{Mg}$ and V. Soil analyzes were carried out following the methods described in Embrapa's manual of soil analysis methods (Teixeira, Donagemma, Fontana, \& Teixeira, 2017) and the samples, five per plot, removed after soybean cultivation.

Data were subjected to analysis of variance (ANOVA) in the ASSISTAT statistical software (Silva \& Azevedo, 2016). When significance occurred, the means were compared using the Tukey test at $5 \%$ probability.

\section{Results and Discussion}

The ANOVA summary, referring to the characteristics evaluated as a function of the application of surface or incorporated limestone (harrow and moldboard plow), associated or not with the application of gypsum in the 2015/16 and 2016/17 seasons are required in Table 2. That in the first year evaluated there was significance ( $\mathrm{p} \leq$ 0.05 ) for characteristic plant height (PH) in the integration of limestone incorporation and acidity management (I * AM). The lack of response for the characteristics evaluated in the first year can be attributed to the lack of time for the input to react. In works developed with the objective of evaluating the effects of liming and plastering, Weirich Neto, Caires, Justino and Dias (2000) found that they affected practices after 3 months of application of the inputs. In the same sense, Caires et al. (2003) also verified the benefits of liming 35 months after its completion.

The second year of evaluation allowed to observe significant differences in many of the evaluated characteristics. Analyzing the results of soil characteristics, in the $0-0.2 \mathrm{~m}$ layer, it is verified that the incorporation of limestone (I) resulted in significance in the calcium content $(\mathrm{Ca})$ and in the source of variation in acidity management (AM), related to the addition of limestone associated or not with the application of gypsum, the significance was given in the characteristics $\mathrm{pH}$, cation exchange capacity (CTC) and $\mathrm{Ca}$ content. The interaction between incorporation method and acidity management resulted in a significant effect for the content aluminum ( $\mathrm{Al}$ ), CTC and base saturation (V). Changes in the chemical characteristics of the soil surface layer due to the application of surface or incorporated limestone, associated or not with gypsum, were also observed by other researchers (Weirich Neto et al., 2000; Caires et al., 2003; Soratto \& Crusciol, 2008; Rampim, Lana, Frandoloso, 
\& Fontaniva, 2011; Souza et al., 2012; Pauletti, Pierri, Ranzan, Barth, \& Motta, 2014; Zandoná, Beutler, Burg, Barreto, \& Schmidt, 2015).

Table 2. Summary of the analysis of variance with significance level in the agricultural years 2015/16 and 2016/17 for data on chemical attributes of soil and productivity in soybean area with different methods of incorporation of limestone associated or not with gypsum in Rio Verde/GO

\begin{tabular}{|c|c|c|c|c|c|c|c|c|c|c|c|c|c|}
\hline \multirow{2}{*}{ SV } & \multirow{2}{*}{ DF } & \multicolumn{6}{|c|}{$2015 / 16$} & \multicolumn{6}{|c|}{$2016 / 17$} \\
\hline & & $\mathrm{pH}$ & $\mathrm{Al}$ & CTC & $\mathrm{Ca}$ & $\mathrm{Mg}$ & $\mathrm{V}$ & $\mathrm{pH}$ & $\mathrm{Al}$ & CTC & $\mathrm{Ca}$ & $\mathrm{Mg}$ & $\mathrm{V}$ \\
\hline \multicolumn{14}{|l|}{$0-0.2 \mathrm{~m}$} \\
\hline I & 2 & $\mathrm{~ns}$ & ns & ns & ns & ns & $\mathrm{ns}$ & ns & ns & ns & $*$ & ns & ns \\
\hline AM & 2 & $\mathrm{~ns}$ & ns & ns & ns & $\mathrm{ns}$ & $\mathrm{ns}$ & $*$ & ns & $*$ & $*$ & $\mathrm{~ns}$ & ns \\
\hline I*AM & 4 & $\mathrm{~ns}$ & ns & ns & ns & ns & ns & $\mathrm{ns}$ & $*$ & $*$ & $\mathrm{~ns}$ & $\mathrm{~ns}$ & $*$ \\
\hline Block & 3 & ns & ns & ns & ns & $\mathrm{ns}$ & $\mathrm{ns}$ & $\mathrm{ns}$ & ns & $\mathrm{ns}$ & ns & $\mathrm{ns}$ & ns \\
\hline Error & 24 & $\mathrm{~ns}$ & ns & ns & $\mathrm{ns}$ & $\mathrm{ns}$ & $\mathrm{ns}$ & ns & $\mathrm{ns}$ & ns & $\mathrm{ns}$ & $\mathrm{ns}$ & $\mathrm{ns}$ \\
\hline$C V(\%)$ & - & 10.9 & 52.6 & 16.9 & 33.5 & 36.9 & 27.1 & 4.7 & 67.8 & 11.0 & 20.0 & 31.6 & 17.6 \\
\hline \multicolumn{14}{|c|}{$0.2-0.4 \mathrm{~m}$} \\
\hline I & 2 & $\mathrm{~ns}$ & ns & ns & ns & ns & ns & $*$ & $\mathrm{~ns}$ & ns & ns & ns & ns \\
\hline $\mathrm{AM}$ & 2 & $\mathrm{~ns}$ & ns & ns & ns & $\mathrm{ns}$ & ns & $*$ & ns & ns & ns & $\mathrm{ns}$ & $\mathrm{ns}$ \\
\hline I*AM & 4 & $\mathrm{~ns}$ & ns & ns & ns & ns & ns & ns & $*$ & $*$ & $*$ & $*$ & $*$ \\
\hline Block & 3 & $\mathrm{~ns}$ & ns & ns & ns & $\mathrm{ns}$ & ns & $\mathrm{ns}$ & ns & ns & $\mathrm{ns}$ & $\mathrm{ns}$ & ns \\
\hline Error & 24 & $\mathrm{~ns}$ & ns & $\mathrm{ns}$ & $\mathrm{ns}$ & $\mathrm{ns}$ & $\mathrm{ns}$ & ns & $\mathrm{ns}$ & $\mathrm{ns}$ & $\mathrm{ns}$ & ns & $\mathrm{ns}$ \\
\hline \multirow[t]{2}{*}{$C V(\%)$} & - & 9.6 & 41.4 & 21.2 & 58.0 & 53.3 & 42.9 & 2.9 & 33.5 & 13.1 & 27.8 & 28.8 & 24.9 \\
\hline & & & $\mathrm{PH}$ & $\mathrm{NP}$ & PROD & & & & $\mathrm{PH}$ & NP & PROD & & \\
\hline I & 2 & & ns & ns & ns & & & & ns & ns & ns & & \\
\hline $\mathrm{AM}$ & 2 & & ns & ns & ns & & & & $*$ & ns & ns & & \\
\hline I*AM & 4 & & $*$ & $\mathrm{~ns}$ & ns & & & & ns & $*$ & $*$ & & \\
\hline Block & 3 & & ns & ns & ns & & & & ns & ns & ns & & \\
\hline Error & 24 & & $\mathrm{~ns}$ & $\mathrm{~ns}$ & ns & & & & $\mathrm{ns}$ & $\mathrm{ns}$ & $\mathrm{ns}$ & & \\
\hline$C V(\%)$ & - & & 6.4 & 18.2 & 7.2 & & & & 12.8 & 13.1 & 5.8 & & \\
\hline
\end{tabular}

Note. SV: Source of variation; I: incorporation; AM: acidity management; DF: Degree of freedom. ns: not significant; * significant at 5\% probability; CTC: cation exchange capacity V: base saturation; PH: plant height, NP: number of pods; PROD: productivity.

The subsurface soil layer (0.2-0.4 m) showed significance for $\mathrm{pH}$ in the sources of variation, incorporation and management of acidity alone. The interaction between the sources of variation resulted in significance in the contents of $\mathrm{Al}, \mathrm{Ca}$ and $\mathrm{Mg}, \mathrm{CTC}$ and V. Similar results were found in works using limestone and/or gypsum applied superficially and incorporated (Caires et al., 2003; Rampim et al., 2011; Souza et al., 2012; Dalla Nora, Amado, Girardello \& Mertins, 2013; Pauletti et al., 2014; Zandoná et al., 2015).

ANOVA for the characteristics evaluated in soybean indicated a significant effect on plant height $(\mathrm{PH})$ due to acidity management (AM) and the interaction between incorporation and acidity management was significant in the number of pods per plant (NP) and in crop yield (PROD). Significant effects on productivity components were observed in the cultivation of rice and beans (Soratto, Crusciol, \& Mello, 2010), wheat (Rampim et al., 2011; Pauletti et al., 2014), millet (Carvalho \& Nascente, 2014), black oats (Pauletti et al., 2014), corn and soybeans (Joris, Caires, Bini, Scharr, \& Haliski, 2013; Pauletti et al., 2014; Zandoná et al., 2015) and angico and canafístula (Vargas \& Marques, 2017).

The splitting of ANOVA for the first year of evaluation of the experiment (2015/16) shows that the incorporation of limestone with moldboard provided the highest soybean PH. However, the use of limestone associated with the application of gypsum provided higher PH when the limestone was applied superficially (Figure 1). 


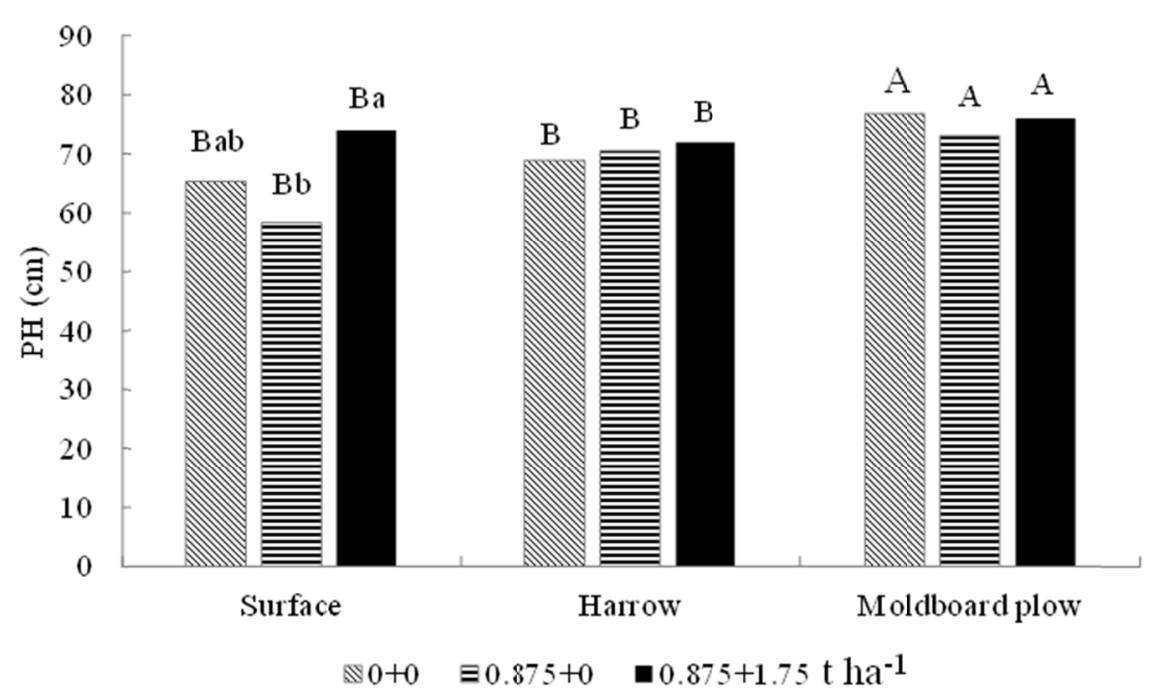

Figure 1. Height of soybean plants $(\mathrm{PH})$ in a production area with different limestone incorporation managements in the 2015/16 crop year in Rio Verde/GO. Uppercase (incorporation) and lowercase (acidity management) equal, do not differ by Tukey test at $\mathrm{p} \leq 0.05$

The developments of ANOVA in the 2016/17 harvest, make it possible to observe that there was an increase in the $\mathrm{Ca}$ content in the surface layer of the soil, when surface limestone was applied and with the use of the harrow. The use of moldboard plow provided an increase in $\mathrm{pH}$ in the subsurface soil layer and in the height of soybean plants (Table 3). The method of incorporation of limestone into the soil determines the efficiency of liming at the depth that is desired to neutralize the acidity (Weirich Neto et al., 2000). In this sense, the increase in Ca in the soil surface layer was also evidenced by Souza et al. (2012) evaluating soil chemical changes under no-tillage and by Pauletti et al. (2014) studying the residual effect of liming and plastering.

The increase in $\mathrm{pH}$ in the subsurface layer, due to limestone incorporation, as in this work, was observed by Caires et al. (2003), and Ernani, Ribeiro, and Bayer (2001). When limestone was applied superficially, there was an increase in the subsoil $\mathrm{pH}$ after 11 months of its application, remaining stable until 35 months after liming (Caires et al., 2003). The occurrence of larger plants due to the use of moldboard plow can be explained by this way of incorporation, increasing the $\mathrm{pH}$ and $\mathrm{Ca}$ content in the subsoil, benefiting the environment for the development of roots, which allows the growth of the aerial part. Vargas and Marques (2017) observed that limestone and gypsum favored the growth and nutrition of Angico and Canafistula.

Table 3. Ca content in the 0-0.2 $\mathrm{m}$ layer and $\mathrm{pH}$ in the $0.20-0.4 \mathrm{~m}$ layer of the soil and plant height $(\mathrm{PH})$ in a soybean production area with different limestone incorporation managements in the 2016/17 crop year in Rio Verde/GO

\begin{tabular}{llll}
\hline \multirow{2}{*}{ Incorporation } & $0-0.2 \mathrm{~m}$ & $0.2-0.4 \mathrm{~m}$ & \multirow{2}{*}{$\mathrm{PH}(\mathrm{cm})$} \\
\cline { 2 - 3 } & $\mathrm{Ca}\left(\mathrm{cmol}_{\mathrm{c}} \mathrm{dm}^{-3}\right)$ & $\mathrm{pH}$ & $62.00 \mathrm{~B}$ \\
Surface & $1.91 \mathrm{~A}$ & $4.19 \mathrm{AB}$ & $67.90 \mathrm{AB}$ \\
Harrow & $1.99 \mathrm{~A}$ & $4.30 \mathrm{~B}$ & $73.05 \mathrm{~A}$ \\
Moldboard plow & $1.59 \mathrm{~B}$ & $4.38 \mathrm{~A}$ & \\
\hline
\end{tabular}

Note. Equal capital letters in the columns do not differ by Tukey test at $\mathrm{p} \leq 0.05$.

Assessing the efficiency of limestone associated or not with the application of gypsum, it is observed in Table 4 that both practices resulted in significant effects on the soil. Limestone associated or not with the use of gypsum allowed an increase in $\mathrm{pH}$ and $\mathrm{Ca}$ content in the soil in the 0-0.2 $\mathrm{m}$ layer. On the other hand, the association of limestone and gypsum provided an increase in $\mathrm{pH}$ in the subsurface soil layer.

Similar results are found in the literature. The change in surface $\mathrm{pH}$ due to the use of limestone was evident in the 0-0.05 m layer, after 11 months of liming, and in the 0.05-0.1 and 0.1-0.2 m depths, after 23 months (Caires et al., 2003). Long-term effects of lime application in the no-tillage system were studied by Pauletti et al. (2014). 
The authors observed that the concentration of $\mathrm{Ca}$ and the $\mathrm{pH}$ in the superficial layers of the soil increased. On the other hand, the use of gypsum provided an increase in Ca in the subsurface of the soil (Caires et al., 2003; Rampim et al., 2011; Zandoná et al., 2015).

Table 4. Ca content and $\mathrm{pH}$ in the $0-0.2$ and $0.2-0.4 \mathrm{~m}$ layers of the soil in a soybean production area with different limestone incorporation managements in the 2016/17 season in Rio Verde/GO

\begin{tabular}{|c|c|c|c|}
\hline \multirow{2}{*}{ Acidity management $\left(\mathrm{t} \mathrm{ha}^{-1}\right)$} & \multicolumn{2}{|c|}{$0-0.2 \mathrm{~m}$} & \multirow{2}{*}{$\begin{array}{l}0.2-0.4 \mathrm{~m} \\
\mathrm{pH}\end{array}$} \\
\hline & $\mathrm{pH}$ & $\mathrm{Ca}\left(\mathrm{cmol}_{\mathrm{c}} \mathrm{dm}^{-3}\right)$ & \\
\hline $0+0$ & $4.67 b$ & $1.48 \mathrm{~b}$ & $4.20 \mathrm{~b}$ \\
\hline $0.875+0$ & $4.50 \mathrm{a}$ & $1.89 \mathrm{a}$ & $4.32 \mathrm{ab}$ \\
\hline $0.875+1.75$ & $5.11 \mathrm{a}$ & $2.12 \mathrm{a}$ & $4.35 \mathrm{a}$ \\
\hline
\end{tabular}

Note. Lowercase letters equal, in columns, do not differ by Tukey test at $\mathrm{p} \leq 0.05$.

The use of gypsum increasing the subsoil pH was also observed by Caires et al. (2003) studying soil chemical changes and soybean response to lime and gypsum applied in the implementation of the no-tillage system. Pauletti et al. (2014) evaluating the long-term effects of the application of gypsum and limestone in the no-tillage system also mention that gypsum provided an increase in $\mathrm{pH}$ in depth.

Table 5 shows the results of the incorporation method interaction with the use of limestone associated or not with the application of gypsum for the characteristics Al, CTC and V at depths of 0-0.2 and 0.2-0.4 m of soil. In the 0-0.2 m layer, it is observed that the use of moldboard plow provided a reduction in CTC where limestone was not applied $\left(0+0 \mathrm{tha}^{-1}\right)$. This could be due to deeper soil tillage, where deeper layers, which normally have lower CTC, were brought up.

The effect of acidity management can be verified in the Al and V characteristics of the $0-0.2 \mathrm{~m}$ layer. When the application was superficial, the use of limestone and gypsum $\left(0.875+1.75 \mathrm{t} \mathrm{ha}^{-1}\right)$ reduced the Al contents in the 0-0.2 m layer of soil when compared to the treatment without application of the inputs $\left(0+0 \mathrm{t} \mathrm{ha}^{-1}\right)$. Such reductions in the surface layer were found in the evaluation of the residual effect of liming and plastering in no-till (Pauletti et al., 2014). Soil V increased with the use of limestone and gypsum $\left(0.875+1.75 \mathrm{t} \mathrm{ha}^{-1}\right)$, when limestone was applied superficially and incorporated by the harrow. Similar results were observed by Weirich Neto et al. (2000) studying the correction of soil acidity as a function of limestone incorporation types.

Incorporation effects were more evident in the subsurface soil layer (Table 5). Al was reduced with the use of moldboard plow, regardless of limestone and gypsum application. As the moldboard plow has a greater effective operating depth than the harrow, this one provides the inversion (mixing) of the soil layers with greater efficiency. This is particularly evident in the treatment without input application $\left(0+0 \mathrm{t} \mathrm{ha}^{-1}\right)$. Consequently, the soil layer with the highest fertility starts to mix with the lowest, resulting in improvements in the chemical properties of the subsurface layer. A similar result was found by Zandoná et al. (2015). Caires et al. (2003) found low levels of exchangeable $\mathrm{Al}$ in the subsoil layers $\left(3\right.$ to $5 \mathrm{mmolc} \mathrm{dm}^{-3}$ ), which previously had the presence of $\mathrm{Al}^{3+}$ in toxic concentration $\left(8 \mathrm{mmolc} \mathrm{dm}^{-3}\right)$. However, for characteristic $\mathrm{V}$, the moldboard plow provided increases when limestone $\left(0.875+0 \mathrm{tha}^{-1}\right)$ and limestone with gypsum $\left(0.875+1.75 \mathrm{tha}^{-1}\right)$ were used. This was expected due to the way the moldboard plow works the soil layers and, in addition, the inputs used make it possible to increase the sum of bases, a component of the V of the soil. According to Weirich Neto et al. (2000), the mode of incorporation of limestone in soil influences its efficiency in relation to depth resulting in an increase in soil V, due to the addition of $\mathrm{Ca}$ (limestone and gypsum) and $\mathrm{Mg}$ (limestone) (Soratto \& Crusciol, 2008; Vargas \& Marques, 2017).

CTC increased when limestone was applied superficially and when incorporated by harrow. With regard to the efficiency of inputs in the subsurface soil layer, it is possible to observe that the association of limestone with gypsum $\left(0.875+1.75 \mathrm{t} \mathrm{ha}^{-1}\right)$ provided an increase in base saturation when they were incorporated into the soil by harrow and moldboard plow. Possibly the use of moldboard plow carried the limestone to a layer of 0.2-0.4 m, since its effective operating depth is around $0.3 \mathrm{~m}$. Similar results were found by Ciotta, Bayer, Fontoura, Ernani, and Albuquerque, (2003), where the action of limestone increased the CTC between no-tillage and conventional planting systems (with and without limestone incorporation). Neis, Paulino, Souza, Reis, and Pinto (2010) also found an increase in CTC with application of gypsum and limestone, but in their work, CTC was higher in the treatment without soil tillage. 
Table 5. Al content, CTC and base saturation (V) of the soil in the 0-0.2 and 0.2-0.4 m layers of the soil in a soybean production area with different limestone incorporation managements in the 2016/17 crop in Rio Verde/GO

\begin{tabular}{|c|c|c|c|c|c|c|c|c|c|}
\hline \multirow{2}{*}{ I } & \multicolumn{3}{|c|}{$\mathrm{Al}\left(\mathrm{cmolc} \mathrm{dm}^{-3}\right)$} & \multicolumn{3}{|c|}{ CTC $\left(\mathrm{cmolc} \mathrm{dm}^{-3}\right)$} & \multicolumn{3}{|c|}{ V (\%) } \\
\hline & $\mathrm{AM}_{0+0}$ & $\mathrm{AM}_{0.875+0}$ & $\mathrm{AM}_{0.875+1.75}$ & $\mathrm{AM}_{0+0}$ & $\mathrm{AM}_{0.875+0}$ & $\mathrm{AM}_{0.875+1.75}$ & $\mathrm{AM}_{0+0}$ & $\mathrm{AM}_{0.875+0}$ & $\mathrm{AM}_{0.875+1.75}$ \\
\hline \multicolumn{10}{|c|}{$0-0.2 \mathrm{~m}$} \\
\hline S & $0.20 \mathrm{~b}$ & $0.10 \mathrm{ab}$ & $0.06 \mathrm{a}$ & 7.40AB & 6.94 & 7.03 & $32.60 \mathrm{~b}$ & $43.72 \mathrm{ab}$ & $47.97 \mathrm{a}$ \\
\hline $\mathrm{H}$ & 0.15 & 0.05 & 0.06 & $8.21 \mathrm{~A}$ & 7.99 & 7.44 & $32.63 b$ & $41.80 \mathrm{a}$ & $43.31 \mathrm{a}$ \\
\hline M & 0.16 & 0.08 & 0.07 & $6.31 \mathrm{~B}$ & 6.78 & 6.52 & 31.99 & 38.59 & 38.6 \\
\hline \multicolumn{10}{|c|}{$0.2-0.4 \mathrm{~m}$} \\
\hline S & $0.42 \mathrm{~B}$ & $0.34 \mathrm{~B}$ & $0.31 \mathrm{~B}$ & 7.34 & 6.67 & $7.12 \mathrm{~A}$ & 11.54 & $12.86 \mathrm{~B}$ & $14.62 \mathrm{~B}$ \\
\hline $\mathrm{H}$ & $0.37 \mathrm{~B}$ & $0.26 \mathrm{AB}$ & $0.30 \mathrm{~B}$ & 8.28 & 7.24 & $7.20 \mathrm{~A}$ & $13.42 \mathrm{~b}$ & $15.48 \mathrm{ABab}$ & $19.60 \mathrm{ABa}$ \\
\hline M & $0.26 \mathrm{~A}$ & $0.21 \mathrm{~A}$ & $0.18 \mathrm{~A}$ & 9.70 & 6.52 & $6.74 \mathrm{~B}$ & $18.19 \mathrm{~b}$ & $22.73 \mathrm{Aab}$ & $25.28 \mathrm{Aa}$ \\
\hline
\end{tabular}

Note. I: incorporation; S: surface, H: harrow; M: moldboard plow; AM: acidity management (limestone and gypsum $\left(\mathrm{t} \mathrm{ha}^{-1}\right)$ ). Equal uppercase letters in columns and equal lowercase letters in rows do not differ by Tukey's test at $\mathrm{p} \leq 0.05$.

Table 6 shows the results of the interaction method of incorporation and acidity management for $\mathrm{Ca}$ and $\mathrm{Mg}$ characteristics at a depth of 0.2-0.4 m of soil. It is observed that there was an effect of incorporation in the treatments where limestone was applied individually $\left(0+1.75 \mathrm{tha}^{-1}\right)$ and together with gypsum $(0.875+1.75 \mathrm{t}$ $\mathrm{ha}^{-1}$ ), with moldboard plow being the method which provided higher contents of $\mathrm{Ca}$ and $\mathrm{Mg}$ in the subsurface. It is also highlighted that the subsurface $\mathrm{Ca}$ increased when the limestone was incorporated by moldboard plow and with plastering $\left(0.875+1.75 \mathrm{tha}^{-1}\right)$. These results were also observed by Caires et al. (2003), Zandoná et al. (2015), Neis et al. (2010) where the Mg applied superficially resulted in more homogeneous contents up to $0.1 \mathrm{~m}$ in depth, when compared to incorporation with plow and harrow.

Table 6. Ca and Mg content in the 20-40 m layer of the soil in a soybean production area with different lime incorporation management in the 2016/17 season in Rio Verde/GO

\begin{tabular}{llllllll}
\hline \multirow{2}{*}{ Incorporation } & \multicolumn{3}{c}{$\mathrm{Ca}\left(\mathrm{cmol}_{\mathrm{c}} \mathrm{dm}^{-3}\right)$} & & \multicolumn{3}{c}{$\mathrm{Mg}\left(\mathrm{cmol}_{\mathrm{c}} \mathrm{dm}^{-3}\right)$} \\
\cline { 2 - 4 } \cline { 7 - 8 } & $\mathrm{AM}_{0+0}$ & $\mathrm{AM}_{0.875+0}$ & $\mathrm{AM}_{0.875+1.75}$ & & $\mathrm{AM}_{0+0}$ & $\mathrm{AM}_{0.875+0}$ & $\mathrm{AM}_{0.875+1.75}$ \\
\hline Surface & 0.58 & $0.58 \mathrm{~B}$ & $0.74 \mathrm{~B}$ & & 0.14 & $0.17 \mathrm{~B}$ & $0.20 \mathrm{~B}$ \\
Harrow & 0.75 & $0.72 \mathrm{AB}$ & $0.91 \mathrm{AB}$ & & 0.24 & $0.28 \mathrm{AB}$ & $0.33 \mathrm{AB}$ \\
Moldboard plow & $0.85 \mathrm{~b}$ & $0.99 \mathrm{Aab}$ & $1.29 \mathrm{Aa}$ & & 0.25 & $0.38 \mathrm{~A}$ & $0.37 \mathrm{~A}$
\end{tabular}

Note. AM: acidity management (limestone and gypsum $\left(\mathrm{t} \mathrm{ha}^{-1}\right)$ ). Equal uppercase letters in columns and equal lowercase letters in rows do not differ by Tukey's test at $\mathrm{p} \leq 0.05$.

Soybean responded significantly to the methods of incorporation of limestone associated or not with gypsum in the 2016/17 harvest (Table 7). The number of pods was influenced in the interaction, by the incorporation method, being the moldboard plow responsible for increases in this characteristic. On the other hand, soybean productivity was influenced by the use of inputs.

It is seen in the treatment with the use of moldboard plow that the soybean yield responded positively to the application of limestone $\left(0.875+0.0 \mathrm{t} \mathrm{ha}^{-1}\right)$ and limestone with gypsum $\left(0.875+1.75 \mathrm{t} \mathrm{ha}^{-1}\right)$. The isolated application of corrective $\left(0.875+0 \mathrm{t} \mathrm{ha}^{-1}\right)$ provided an increase in productivity of $398 \mathrm{~kg} \mathrm{ha}^{-1}$ and when liming and plastering $\left(0.875+1.75 \mathrm{t} \mathrm{ha}^{-1}\right)$ were performed, the increase was $453 \mathrm{~kg} \mathrm{ha}^{-1}$. It is noteworthy that the 0.875 $+0 \mathrm{tha}^{-1}$ and $0.875+1.75 \mathrm{tha}^{-1}$ treatments differed from the $0+0 \mathrm{t} \mathrm{ha}^{-1}$ treatment, but they did not differ from each other.

The results found on the components of crop productivity are still controversial. Liming brought improvements to the production of bean cultivars and gypsum reduced panicles in rice and number of pods in beans, but did not affect the productivity of both (Soratto, Crusciol, \& Mello 2010). The application of limestone increased the productivity of soybean, corn (Joris et al., 2013; Pauletti et al., 2014), black oat (Pauletti et al., 2014) and increased dry biomass of millet (Carvalho \& Nascente, 2014). 
Table 7. Number of pods (NP) and yield (PROD) of soybean with different limestone incorporation managements in the 2016/17 harvest in Rio Verde/GO

\begin{tabular}{|c|c|c|c|c|c|c|}
\hline \multirow{2}{*}{ Incorporation } & \multicolumn{3}{|c|}{ NP } & \multicolumn{3}{|c|}{$\operatorname{PROD}\left(\mathrm{kg} \mathrm{ha}^{-1}\right)$} \\
\hline & $\mathrm{AM}_{0+0}$ & $\mathrm{AM}_{0.875+0}$ & $\mathrm{AM}_{0.875+1.75}$ & $\mathrm{AM}_{0+0}$ & $\mathrm{AM}_{0.875+0}$ & $\mathrm{AM}_{0.875+1.75}$ \\
\hline Surface & $43.10 \mathrm{~B}$ & $45.40 \mathrm{~B}$ & $47.45 \mathrm{~B}$ & 3.657 & 3870 & 4026 \\
\hline Harrow & $48.70 \mathrm{AB}$ & $47.05 \mathrm{AB}$ & $54.05 \mathrm{~B}$ & 3.714 & 3918 & 3962 \\
\hline Moldboard plow & $50.40 \mathrm{~A}$ & $48.70 \mathrm{~A}$ & $56.70 \mathrm{~A}$ & $3.456 \mathrm{~b}$ & $3854 a$ & $3909 a$ \\
\hline
\end{tabular}

Note. AM: acidity management (limestone and gypsum $\left(\mathrm{t} \mathrm{ha}^{-1}\right)$ ). Equal uppercase letters in columns and equal lowercase letters in rows do not differ by Tukey's test at $\mathrm{p} \leq 0.05$.

Gypsum provided increases in wheat production in soils with high Al content (Rampim et al., 2011), favored the productivity of corn, soybean (Pauletti et al., 2014; Zandoná et al., 2015) and wheat when under water stress (Pauletti et al., 2014). On the other hand, Caires et al. (2003) did not find benefits from the application of limestone and gypsum in 3 consecutive soybean crops. Likewise, the surface application of limestone and gypsum did not increase the dry matter of black oat (Soratto \& Crusciol, 2008) and oat and ryegrass (Silva et al., 2015).

The results obtained show that the management adopted in some production areas in the Southwest region of Goiás, which in many situations do not fit the prescription liming recommendations (considering established methodologies for calculating the need for correctives and conditioning), were influenced by the method incorporation of limestone and the association of liming with gypsum. It is noteworthy that adjustments in soil fertility management are possible, but there is a need for technical monitoring and knowledge of the management history of production areas.

\section{Conclusions}

The incorporation of limestone by harrow increased the Ca content in the $0-0.20 \mathrm{~m}$ layer of soil. The use of limestone, associated or not with gypsum, increased the surface and subsurface $\mathrm{pH}$ and the Ca content in the soil surface layer. The moldboard plow reduced $\mathrm{Al}$ content and increased subsurface $\mathrm{Ca}, \mathrm{Mg}$ and $\mathrm{V}$ and the number of pods per soybean plant. The use of limestone and gypsum on surface reduced $\mathrm{Al}$ and when incorporated by the harrow increased $\mathrm{V}$ in the 0-0.2 $\mathrm{m}$ layer. The incorporation of limestone by moldboard plow, associated or not with gypsum provided an increase in soybean productivity in the 2016/2017 harvest.

\section{Acknowledgments}

This work was supported by the University of Rio Verde and was financed by Coordination for the Improvement of Higher Education Personnel (CAPES), the National Council for Scientific and Technological Development and the Foundation for Research Support of the State of Goiás (FAPEG), and the Agroindustrial Cooperative of Rural Producers of Southwest Goiás (COMIGO). Our special thanks to the researchers Álisson Vanin and Dieimisson Paulo Almeida, who helped in some of the stages of this work.

\section{References}

Caires, E. F., Blum, J., Barth, G., Garbuio, F. J., \& Kusman, M. T. (2003). Alterações químicas do solo e resposta da soja ao calcário e gesso aplicados na implantação do sistema plantio direto. Revista Brasileira de Ciência do Solo, 27(2), 275-286. https://doi.org/10.1590/S0100-06832003000200008

Caires, E. F., Garbuio, F. J., Churka, S., Barth, G., \& Corrêa, J. C. L. (2008). Effects of soil acidity amelioration by surface liming on no-till corn, soybean, and wheat root growth and yield. European Journal of Agronomy, 28(1), 57-64. https://doi.org/10.1016/j.eja.2007.05.002

Carvalho, M. C. S., \& Nascente, A. S. (2014). Calcário, gesso e efeito residual de fertilizantes na produção de biomassa e ciclagem de nutrientes de milheto. Pesquisa Agropecuária Tropical, 44(4), 370-380. https://doi.org/10.1590/S1983-40632014000400008

Ciotta, M. N., Bayer, C., Fontoura, S. M. V., Ernani, P. R., \& Albuquerque, J. A. (2003). Matéria orgânica e aumento da capacidade de troca de cátions em solo com argila de baixa atividade sob plantio direto. Ciência Rural, 33(6), 1161-1164. https://doi.org/10.1590/S0103-84782003000600026

Dalla Nora, D. D., Amado, T. J. C., Girardello, V. C., \& Mertins, C. (2013). Gesso: alternativa para redistribuir verticalmente nutrientes no perfil do solo sob sistema plantio direto. Revista Plantio Direto, 133, 8-20. 
Ernani, P. R., Ribeiro, M. S., \& Bayer, C. (2001). Modificações químicas em solos ácidos ocasionadas pelo método de aplicação de corretivos da acidez e de gesso agrícola. Scientia Agricola, 58(4), 825-831. https://doi.org/10.1590/S0103-90162001000400026

Ferreira, R. V., Tavares, R. L. M., Medeiros, S. F., Silva, A. G., \& Silva Júnior, J. F. (2020). Carbon stock and organic fractions in soil under monoculture and Sorghum bicolor-Urochloa ruziziensis intercropping systems. Soil and Plant Nutrition, 79(3), 425-433. https://doi.org/10.1590/1678-4499.20200042

Joris, H. A. W., Caires, E. F., Bini, A. R., Scharr, D. A., \& Haliski, A. (2013). Effects of soil acidity and water stress on corn and soybean performance under a no-till system. Plant Soil, 365, 409-424. https://doi.org/ $10.1007 / \mathrm{s} 11104-012-1413-2$

Marchi, G., Spehar, C. R., Sousa-Silva, J. C., Guilherme, L. R. G., \& Martins, E. S. (2020). Research perspectives on the use of phosphogypsum in the Brazilian Cerrado. Journal of Agriculture Food and Development, 6, 22-30. https://doi.org/10.30635/2415-0142.2020.06.03

Neis, L., Paulino, H. B., Souza, E. D. de, Reis, E. F. dos, \& Pinto, F. A. (2010). Gesso agrícola e rendimento de grãos de soja na região do Sudoeste de Goiás. Revista Brasileira Ciência do Solo, 34(2), 409-416. https://doi.org/10.1590/S0100-06832010000200014

Pauletti, V., Pierri, L. de, Ranzan, T., Barth, G., \& Motta, A. C. V. (2014). Efeitos em longo prazo da aplicação de gesso e calcário no sistema de plantio direto. Revista Brasileira de Ciência do Solo, 38(2), 495-505. https://doi.org/10.1590/S0100-06832014000200014

Raij, B. Van, Quaggio, J. A., Cantarella, H., Ferreira, M. E., Lopes, A. S., \& Bataglia, O. C. (1987). Análise química do solo para fins de fertilidade. Campinas, SP: Fundação Cargill.

Rampim, L., Lana, M. C., Frandoloso, J. F., \& Fontaniva, S. (2011). Atributos químicos de solo e resposta do trigo e da soja ao gesso em sistema semeadura direta. Revista Brasileira de Ciência do Solo, 35(5), 1687-1698. https://doi.org/10.1590/S0100-06832011000500023

Sá, J. C. M., Cerri, C. C., Lal, R., Dick, W. A., Piccolo, M. C., \& Feigl, B. E. (2009). Soil organic carbon and fertility interactions affected by a tillage chronosequence in a Brazilian Oxisol. Soil and Tillage Research, 104(1), 56-64. https://doi.org/10.1016/j.still.2008.11.007

Santos, H. G. dos, Jacomine, P. K. T., Anjos, L. H. C. dos, Oliveira, V. A. de, Lumbreras, J. F., Coelho, M. R., ... Cunha, T. J. F. (2018). Sistema Brasileiro de Classificação de solos (5th ed.). Brasília, DF: Embrapa.

Silva, F. A. S., \& Azevedo, C. A. V. (2016). The assistat software version 7.7 and its use in the analysis of experimental data. African Journal of Agriculture Research, 11(39), 3733-3740. https://doi.org/10.5897/ AJAR2016.11522

Silva, M. R., Pelissari, A., Moraes, A. de, Sandini, I. E., Cassol, L. C., Assmann, T. S., \& Oliveira, E. B. (2015). Acumulação de nutrientes e produção forrageira de aveia e azevém em função da aplicação de calcário e gesso em superfície. Revista de Ciências Agrárias, 38(3), 346-356. https://doi.org/10.19084/rca_vol38_n3

Soratto, R. P., \& Crusciol, C. A. C. (2008). Produção de fitomassa e acúmulo de nutrientes pela aveia-preta em função da aplicação de calcário e gesso em superfície na implantação do sistema plantio direto. Ciência Rural, 38(4), 928-935. https://doi.org/10.1590/S0103-84782008000400004

Soratto, R. P., Crusciol, C. A. C. L., \& Mello, F. F. C. (2010). Componentes da produção e produtividade de cultivares de arroz e feijão em função de calcário e gesso aplicados na superfície do solo. Bragantia, 69(4), 965-974. https://doi.org/10.1590/S0006-87052010000400023

Souza, R. F, Rosa Junior, E. J., Fietz, C. R., Bergamin, A. C., Rosa, Y. B. C. J., \& Zeviani, W. M. (2012). Efeito do gesso nas propriedades químicas do solo sob dois sistemas de manejo. Semina: Ciências Agrárias, 33(5), 1717-1732. https://doi.org/10.5433/1679-0359.2012v33n5p1717

Tavares, R. L. M., Assis, R. L., Ferreira, R. V., Menezes, J. F. S., Simon, G. A., Boldrin, P. F., \& Cantão, V. C. G. (2019). Long term application of pig manure on the chemical and physical properties of Brazilian Cerrado soil. Journal Carbon Management, 10(6), 541-549. https://doi.org/10.1080/17583004.2019.1676095

Teixeira, P. C., Donagemma, G. K., Fontana, A., \& Teixeira, W. G. (2017). Manual de métodos de análise do solo (3rd ed.). Brasília, DF: Embrapa.

Vargas, G., \& Marques, R. (2017). Crescimento e nutrição de angico e canafístula sob calagem e gessagem. Floresta Ambiente, 24, e20160102. https://doi.org/10.1590/2179-8087.010216 
Weirich Neto, P. H., Caires, E. F., Justino, A., \& Dias, J. (2000). Correção da acidez do solo em função de modos de incorporação de calcário. Ciência Rural, 30(2), 257-261. https://doi.org/10.1590/S0103-8478200000 0200010

Zandoná, R. R., Beutler, A. N., Burg, G. M., Barreto, C. F., \& Schmidt, M. R. (2015). Gesso e calcário aumentam a produtividade e amenizam o efeito do déficit hídrico em milho e soja. Pesquisa Agropecuária Tropical, 45(2), 128-137. https://doi.org/10.1590/1983-40632015v4530301

\section{Copyrights}

Copyright for this article is retained by the author(s), with first publication rights granted to the journal.

This is an open-access article distributed under the terms and conditions of the Creative Commons Attribution license (http://creativecommons.org/licenses/by/4.0/). 